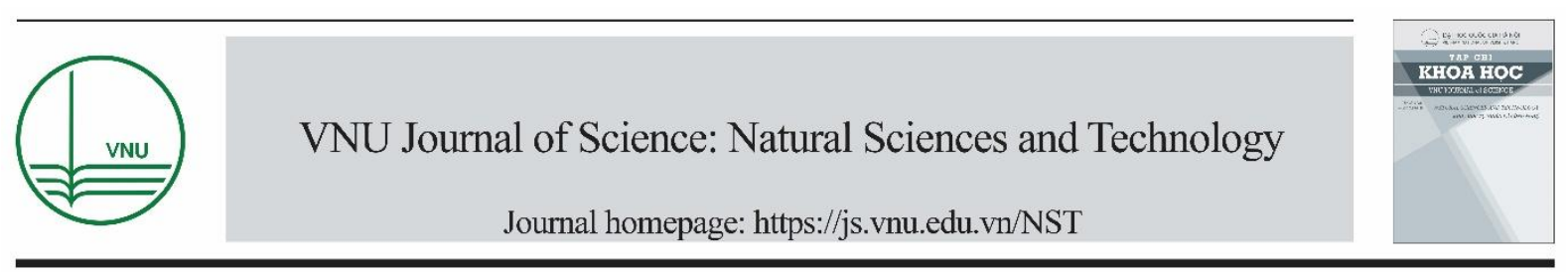

\title{
Original Article \\ Prosaptia Contigua C. Presl (Grammitidaceae), a New Record for Vietnam
}

\author{
Nguyen Cong Toan, Phan Ke Loc, Nguyen Trung Thanh* \\ Faculty of Biology, VNU University of Science, 334 Nguyen Trai, Thanh Xuan, Hanoi, Vietnam \\ Received 9 February 2019 \\ Revised 13 March 2019; Accepted 14 March 2019
}

\begin{abstract}
The specimens of genus Prosaptia C. Presl (family Grammitidaceae) stored in the Herbarium of the University of Science under Vietnam National University were studied with the traditional morphological methods. The study provides descriptions, illustrations and comparisons of 6 species of genus Prosaptia, namely $P$. alata, $P$. barathrophylla, $P$. intermedia, $P$. pectinata, $P$. obliquata and $P$. contigua. Prosaptia contigua (G.Forst.) C.Presl has been identified as a new record for the flora of Vietnam.
\end{abstract}

Keywords: Genus Prosaptia, Prosaptia contigua, Grammitidaceae, new record for the flora of Vietnam.

\section{Introduction}

Grammitidaceae is a family of ferns that distributed mainly in Southeast Asia, including Vietnam. In 1941, Tardieu-Blot M.L. and Christensen C. showed that Vietnam has 4 species belonging to the genus Prosaptia, with namely as: $P$. stenobasis Baker, $P$. obliquatum Mett., $P$. urceolare (Hayata) Copel. and $P$. khasyana (Hook.) C.Chr. \& Tardieu [1]. In 1991, Phạm Hoàng Hộ pointed out that Vietnam has only 2 species: $P$. stenobasis Baker and $P$. urceolare (Hayata) Copel. [2]. In 2010 Phan K.L. showed that Vietnam has only one species,
P. urceolare (Hayata) Copel. [3]. Until recently, the taxonomic concepts of grammitid ferns have been changing considerably under the light of molecular phylogeny. Ctenopteris Blume ex Kunze, Grammitis Sw. s.l. and Xiphopteris Kaulf. formerly widely used names for grammitid ferns, but are now considered to be unsatisfactory artificial genera based on frond dissection. Recent developments in Old World grammitid taxonomy have centred on describing new genera based upon additional morphological characters and two of the three old genera are no longer recognized. The type species of Ctenopteris has been transferred to Prosaptia

\footnotetext{
*Corresponding author.

Email address: thanhntsh@gmail.com

https://doi.org/10.25073/2588-1140/vnunst.4863
} 
C.Presl [4]. In the genus Prosaptia of Vietnam have five-species that were registrated now as Prosaptia alata (Blume) H.Christ (syn. Ctenopteris alata (Blume) Holttum), Prosaptia barathrophylla (Baker) M.G.Price (syn. Ctenopteris barathrophylla (Baker) Parris, P. khasyana auct. non (Hook.) C.Chr. \& Tardieu: Tardieu \& Christensen, Prosaptia intermedia (Ching) Tagawa (syn. P. urceolaris auct. non (Hayata) Copel.: Tardieu \& Christensen, Phan,
Prosaptia obliquata (Blume) Mett. (syn. Ctenopteris obliquata (Blume) Copel.), Prosaptia pectinata T.Moore (syn. P. stenobasis Baker, Ctenopteris leysii (Baker) Holttum) [4]. Specimen HLF5267b stored in the Herbarium HNU of VNU University of Science differs from all of cited species. It is identified by us as Prosaptia contigua (G.Forst.) C. Presl. Thus this is a new record for the fern flora of Vietnam.

Table 1. Comparison of the basic characteristics of the species in the genus Prosaptia encountered in Vietnam

\begin{tabular}{|c|c|c|c|c|c|c|}
\hline Characteristics & $\begin{array}{l}\text { Prosaptia } \\
\text { alata } \\
{[5,6]}\end{array}$ & $\begin{array}{l}\text { Prosaptia } \\
\text { barathrophylla } \\
{[6,7]}\end{array}$ & $\begin{array}{l}\text { Prosaptia } \\
\text { intermedia } \\
{[8]}\end{array}$ & $\begin{array}{l}\text { Prosaptia } \\
\text { oliquata } \\
{[6,9]} \\
\end{array}$ & $\begin{array}{l}\text { Prosaptia } \\
\text { pectinata } \\
{[6]} \\
\end{array}$ & $\begin{array}{l}\text { Prosaptia } \\
\text { contigua }\end{array}$ \\
\hline Stipe & $\begin{array}{l}\text { Short, 5-18 } \\
\text { mm long }\end{array}$ & Very short & $\begin{array}{l}\text { Very short, } 2 \\
\text { mm long }\end{array}$ & $\begin{array}{l}\text { Short, } 14-30 \\
\text { mm long }\end{array}$ & $\begin{array}{l}\text { Winged to } \\
\text { base or } 1-10 \\
\mathrm{~mm} \text { long }\end{array}$ & $\begin{array}{l}\text { Short, } 10-25 \\
\mathrm{~mm} \text { long }\end{array}$ \\
\hline Lamina & $\begin{array}{l}\text { Linear- } \\
\text { lanceolate, } \\
144-270 \times \\
14-25 \mathrm{~mm} \text {, } \\
\text { pinnately } \\
\text { divided to } \\
\text { wing 4.4-8 } \\
\text { mm wide } \\
\text { along rachis }\end{array}$ & $\begin{array}{l}\text { Lanceolate, } \\
120-530 \text { (or } \\
\text { more) } \times 16-30 \\
\text { mm, simply } \\
\text { pinnatifid, wing } \\
2.5-3 \mathrm{~mm} \\
\text { wide. }\end{array}$ & $\begin{array}{l}\text { Narrowly } \\
\text { elliptic, } 110- \\
180 \times 15-21 \\
\text { mm, deeply } \\
\text { pinnately } \\
\text { divided to } \\
\text { wing } 0.5-1.3 \\
\text { mm wide } \\
\text { along rachis }\end{array}$ & $\begin{array}{l}\text { Narrowly } \\
\text { elliptic in } \\
\text { outline, } \\
\text { pinnate or } \\
\text { deeply } \\
\text { pinnately } \\
\text { divided to } \\
\text { wing } 0.1-0.2 \\
\text { mm wide } \\
\text { along rachis }\end{array}$ & $\begin{array}{l}\text { Narrowly } \\
\text { elliptic in } \\
\text { outline, 142- } \\
380 \text { (or } \\
\text { more) x } 31- \\
65 \mathrm{~mm} \text {, } \\
\text { deeply } \\
\text { pinnately } \\
\text { divided to } \\
\text { wing } 0.2-1 \\
\text { mm wide } \\
\text { along rachis. }\end{array}$ & $\begin{array}{l}\text { Linear- } \\
\text { elliptic, 140- } \\
200 \times 18-27 \\
\text { mm, pinnate } \\
\text { or deeply } \\
\text { pinnately } \\
\text { divided to } \\
\text { narrow wing } \\
\text { less than0.8 } \\
\text { mm wide } \\
\text { along rachis. }\end{array}$ \\
\hline Pinn & $\begin{array}{l}25-48 \text { (or } \\
\text { more) pairs, } \\
\text { narrowly } \\
\text { triangular } \\
\text { to narrowly } \\
\text { oblong in } \\
\text { outline, } \\
\text { obtuse to } \\
\text { acute at } \\
\text { apex. }\end{array}$ & $\begin{array}{l}\text { 36-74 (or more) } \\
\text { pairs, very } \\
\text { narrowly } \\
\text { oblong to very } \\
\text { narrowly } \\
\text { triangular, } \\
\text { entire, obtuse } \\
\text { to acute at } \\
\text { apex. }\end{array}$ & $\begin{array}{l}\text { 14-24 (or } \\
\text { more) pairs, } \\
\text { narrowly } \\
\text { triangular } \\
\text { oblong to } \\
\text { narrowly } \\
\text { oblong, entire, } \\
\text { bluntly acute } \\
\text { to acute at } \\
\text { apex. }\end{array}$ & $\begin{array}{l}\text { 40-84 pairs, } \\
\text { linear to } \\
\text { linear- } \\
\text { lanceolate, } \\
\text { acute or } \\
\text { obtuse at } \\
\text { apex. }\end{array}$ & $\begin{array}{l}26-46 \text { pairs, } \\
\text { very } \\
\text { narrowly } \\
\text { triangular to } \\
\text { very } \\
\text { narrowly } \\
\text { oblong, } \\
\text { entire in } \\
\text { sterile } \\
\text { pinnae, } \\
\text { crenate- } \\
\text { undulate } \\
\text { toward } \\
\text { apex on } \\
\text { margin in } \\
\text { fertile ones, } \\
\text { obtuse or } \\
\text { rounded at } \\
\text { apex. }\end{array}$ & $\begin{array}{l}38-52 \text { (or } \\
\text { more) pairs, } \\
\text { very narrowly } \\
\text { oblong } \\
\text { to very } \\
\text { narrowly } \\
\text { triangular- } \\
\text { oblong in } \\
\text { outline obtuse } \\
\text { at apex. }\end{array}$ \\
\hline
\end{tabular}




\begin{tabular}{|c|c|c|c|c|c|c|}
\hline Sori & $\begin{array}{l}\text { Deeply } \\
\text { sunken } \\
\text { oblique or } \\
\text { parallel to } \\
\text { plane of } \\
\text { lamina, } \\
\text { opening at } \\
\text { margin, } \\
\text { lamina } \\
\text { margin } \\
\text { forming part } \\
\text { of pits } \\
\text { mouth. }\end{array}$ & $\begin{array}{l}\text { Sunk in very } \\
\text { distinct round } \\
\text { pits, which do } \\
\text { not show as } \\
\text { papillae on the } \\
\text { upper surface } \\
\text { of the frond, } \\
\text { perpendicular } \\
\text { to plane of } \\
\text { lamina. }\end{array}$ & $\begin{array}{l}\text { Deeply } \\
\text { sunken in } \\
\text { cavities } \\
\text { perpendicular } \\
\text { to lamina } \\
\text { surface with } \\
\text { rim higher on } \\
\text { side nearest } \\
\text { costa, entirely } \\
\text { on abaxial } \\
\text { surface of } \\
\text { lamina. }\end{array}$ & $\begin{array}{l}\text { Sunken } \\
\text { perpendicular } \\
\text { to plane of } \\
\text { lamina in } \\
\text { steep-sided } \\
\text { pits, mouth } \\
\text { entirely on } \\
\text { abaxial } \\
\text { surface of } \\
\text { lamina, rim of } \\
\text { even height. }\end{array}$ & $\begin{array}{l}\text { Sunken } \\
\text { oblique or } \\
\text { parallel to } \\
\text { plane of } \\
\text { lamina in } \\
\text { semicircular } \\
\text { to semi- } \\
\text { elliptic } \\
\text { pouches, } \\
\text { opening at } \\
\text { margin, } \\
\text { lamina } \\
\text { margin } \\
\text { forming part } \\
\text { of pits } \\
\text { mouth. }\end{array}$ & $\begin{array}{l}\text { Sunken in } \\
\text { marginal } \\
\text { urceolate } \\
\text { cavities } \\
\text { opening } \\
\text { outward, } \\
\text { parallel to } \\
\text { plane of } \\
\text { lamina, } \\
\text { lamina } \\
\text { margin } \\
\text { forming of } \\
\text { pits mouth. }\end{array}$ \\
\hline
\end{tabular}

\section{Key to the species of Prosaptia in Vietnam}

1a Sori perpendicular to plane of lamina 2

2a Sori without a raised rim P.barathrophylla

$2 b$ Sori with a rim .3

3a Rim higher on side nearest costa $P$. intermedia

$3 \mathrm{~b}$ Rim of even height P. obliquata

1b Sori oblique or parallel to plane of lamina ...........................................4 4a Rachis wing wide, more than $1 \mathrm{~mm}$, up to $8 \mathrm{~mm}$ P. alata

$4 \mathrm{~b}$ Rachis wing narrow, less than $1 \mathrm{~mm}$ 5

5a Lamina margin forming part of pit mouth P. pectinata

$5 \mathrm{~b}$ Lamina margin forming all of pit mouth P. contigua

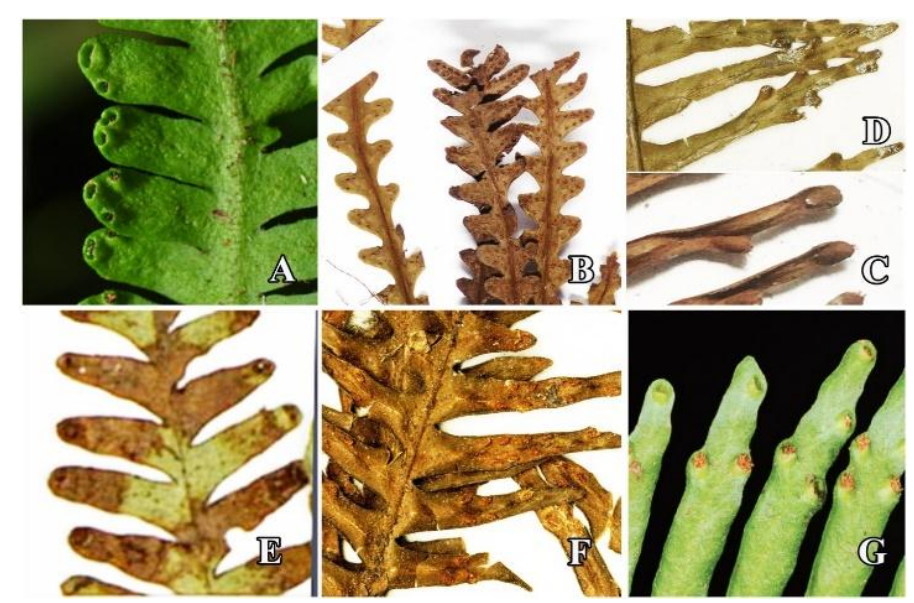

Figure 1. Sori image of species belonging to genus Prosaptia in Vietnam. A. P. intermedia (Blume) Christ; B. P. barathrophylla (Baker) M.G. Price.; C-D. P. contigua (G. Forst.) C. Presl; E. P. intermedia (Ching) Tagawa; F. P. obliquata (Blume) Mett.; G. P. pectinata T. Moore (Photos: A. by Phutthai, T.[10]; B, F. by Nationaal Herbarium Nederland [11]; C. by Toan N.C.; D. by Natural History Museum [12]; E. by Herbarium Universitatis Mosquensis [13]; G. by Pi F.L [14].

Note: It is note worthy that Prosaptia contigua's hairs on the stipe in Vietnam is less than lectotype (BM 000036058!), sometimes lamina sudden decrease at apex. 

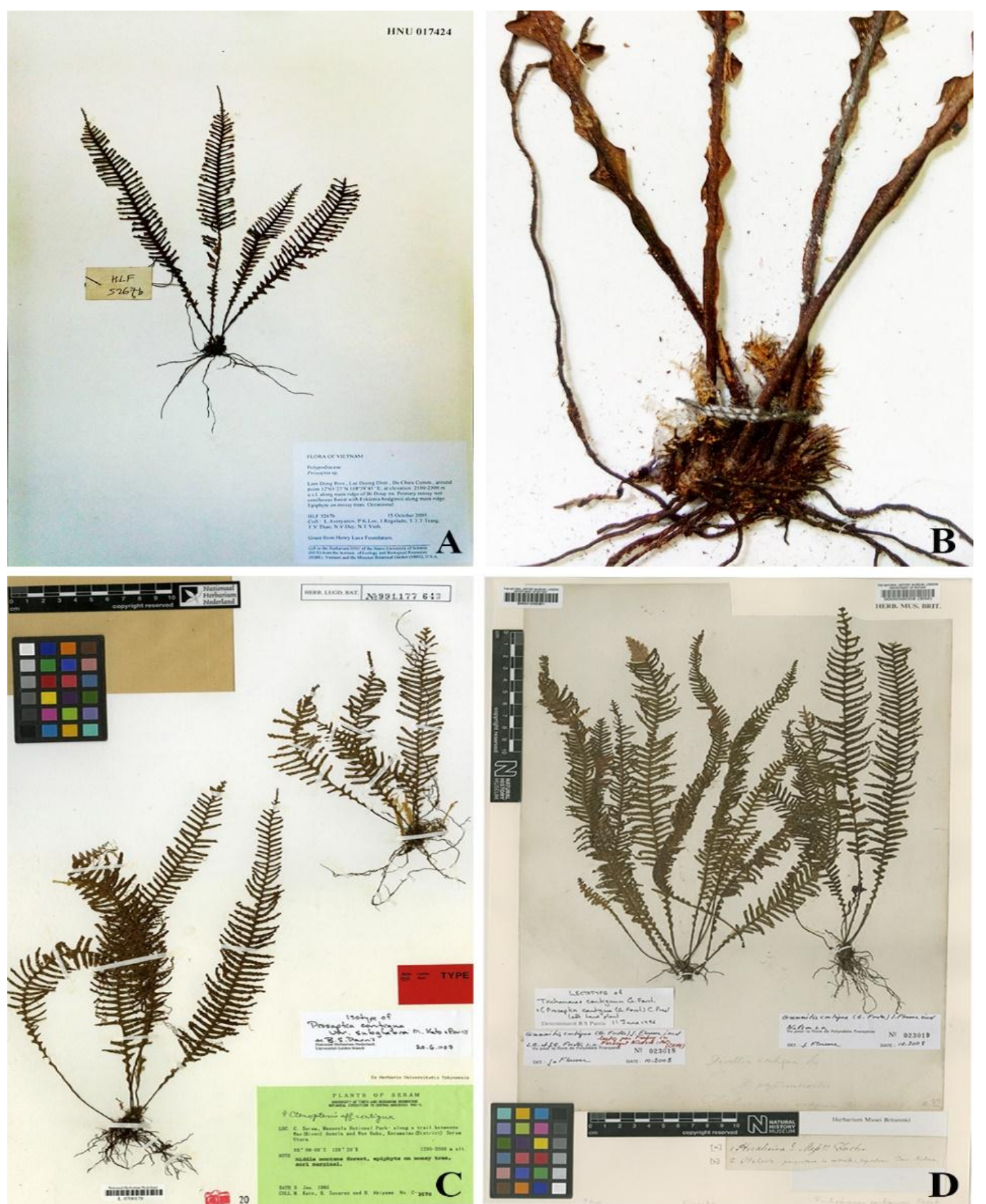

Figure 2. Prosaptia contigua (G.Forst.) C.Presl: A. \& B. L.Averyanov, P.K.Loc, J.Regalado, T.T.T.Trang, T.V.Thao, N.V.Duy and N.T.Vinh. 5267b; M.Kato, C. B.Sunarno and H.Akiyama 3578 (Isotype L 0700179!), retrieved from http://bioportal.naturalis.nl/multimedia/L++0700179_0101692314/term=prosaptia+contigua\&from=119; D. David Nelson s.n. 023019 (Lectotype BM 000036058!), retrieved from http://data.nhm.ac.uk/dataset/collection-specimens/resource/05ff2255-

c38a-40c9-b657-4ccb55ab2feb?_no_cache_=True\&view_id=6ba121d1-da26-4ee1-81fa-

7da11e68f68e\&filters=higherGeography\%3AOceania\%3B\%20French\%20Polynesia\&page=14. 


\section{Description}

Prosaptia contigua (G.Forst.) C.Presl, Tent. Pterid. 166. 1836. Basionym: Trichomanes contiguum G.Forst., Fl. Ins. Austr. 84. 1786. Type: French Polynesia, Oceania, Tahiti, Society Islands - Windward, 11 June 1996, David Nelson s.n. (Lectotype BM 000036058!). Synonym: Ctenopteris contigua (G.Forst.) Holttum, Rev. Fl. Malaysia 2: 230, fig. 130. 1954. Type: C. Seram, Manusela National Park, along a trail between Wae (River) Ansela and Wae Huhu, Kecamatan (District) Seram Utara, Indonesia, 03 Jan. 1985, M.Kato, B.Sunarno and H.Akiyama (Isotype L 0700179!).

Stipe short, $1-2.5 \mathrm{~cm}$ long with occasional to scattered hairs, simple and tufted 2 , sometimes 3 , medium to dark reddish brown, less than $0.7 \mathrm{~mm}$ long.

Lamina linear-elliptic, gradually narrowing towards both ends sometimes sudden decrease at apex, $14-20 \times 1.8-2.7 \mathrm{~cm}$, acuminate at apex, gradually shortened downward to form small deltoid or semicircular pinnae; lamina pinnate or deeply pinnately divided to narrow wing less than $0.8 \mathrm{~mm}$ wide along rachis, $38-52$ (or more) pairs, very narrowly oblong to very narrowly triangular oblong in outline, pinnae ascending, middle pinnae largest, $0.8-1.5 \times 0.1-0.2 \mathrm{~cm}$, dilated at base, obtuse at apex; margins of pinnae entire when sterile, lobed to wing less than $1 \mathrm{~mm}$ wide along pinna midvein when fertile, $1 / 3$ to the apex of the pinnae; rachis prominent on both surfaces of lamina, medium brown or darker, concolorous to darker on both surfaces, terete at base; costae slightly prominent on both surfaces; veins slightly superficial and short, simple; hairs simple, solitary or sometimes tufted 2-3, medium to dark reddish brown, $0.2-0.7 \mathrm{~mm}$, dense and short hairs on abaxial side of rachis, scattered on adaxial side, occasional to scattered on both sides of costae and margin, sparse on both sides of lamina. Sorus 1 per tooth and/or 1 at apex of pinna, 1-4 on each pinna, sunken in marginal urceolate cavities opening outward, parallel to plane of lamina, lamina margin forming of pit mouth, rim of cavity slightly with some short simple hairs on both sides.

Vietnam: Lam Dong Prov., Lac Duong Distr., Da Chais Comm., around point $12^{\circ} 05^{\prime} 27^{\prime \prime} \mathrm{N}, 108^{0} 39^{\prime} 43^{\prime \prime} \mathrm{E}$, at elevation 2100 $2300 \mathrm{~m}$ a.s.l., along main ridge of Bi Doup mountain, 15 Oct. 2005, L.Averyanov, P.K.Loc, J.Regalado, T.T.T.Trang, T.V.Thao, N.V.Duy and N.T.Vinh 5267b.

Distribution- Outside Vietnam: S India, Sri Lanka, Thailand, S China, Taiwan, Sumatra, Peninsular Malaysia, Borneo (Sabah and Sarawak), Java, Lesser Sunda Islands, the Philippines, Sulawesi, Maluku, New Guinea, NE Autralia and the Pacific Island [6];- In Vietnam: Lam Dong Province, Lac Duong District, Da Chais Community, only one specimen was collected.

Ecology- Outside Vietnam: Uncommon epiphyte 0-3 $\mathrm{m}$ up on trees $10-30 \mathrm{~cm}$ diameter and on rotten logs, sometimes by streams, or lithophyte on granite, in ridge crest and valley lower montane forest and ridge crest upper montane forest from 760 to $1700 \mathrm{~m} \mathrm{[6];-} \mathrm{In}$ Vietnam: It is occasional an epiphyte on mossy trees inprimary mossy wet coniferous forest with the dominance of Fokienia hodginsii along main ridge, $2100-2300 \mathrm{~m}$.

\section{Acknowledgements}

The authors would like to thank the Herbarium HNU of VNU University of Science for enabling us to study the specimens here.

\section{References}

[1] M.L. Tardieu-Blot and C. Christensen, Prosaptia C. Presl., In F. Gagnepain, Flore Générale De L'Indo-Chine Tome 7, Part. 2, Fasc.9, Masson et Cié́diteurs, Paris, 1941, pp.528-531.

[2] P.H. Hộ, Cây cỏ Việt Nam, An Illustrated Flora of Vietnam, Quyển I, Tập 1, Montréal, published by the author, 1991, pp.139.

[3] P.K. Loc, The Updated Checklist of the Fern Flora of Vietnam following the classification scheme of 
A. Smith et al., (2006), Fairylake Botanical Garden 9 (3) (2010) 1-13.

[4] B.S. Parris, W.C. Cheng, C.H. Tian, L.T. Ngan, N.Q. Dat, and L.H. Truong, New species and records of grammitid ferns (Polypodiaceae) for Vietnam, Phytotaxa $266 \quad$ (1) (2015) 39. http://doi.org/10.11646/phytotaxa

[5] C.L. Blume, Davallia alata, Enumeratio Plantarum Javae 2, Apud J.W. van Leeuwen, Lugduni Batavorum (Leiden), 1928, pp. 230.

[6] B.S. Parris, 40. Grammitidaceae - 7. Prosaptia. In B.S. Parris, R. Kiew, R.C.K. Chung, L.G. Saw \& E. Seopadmo eds, Flora of Peninsular Malaysia, Ser. I. Ferns and Lycophytes, Malaysia 1 (2010) 170-182.

[7] J.G. Baker, Polypodium barathrophyllum J. Bot. 29 (1891)107-108.
[8] S.J. Moore and B.S. Parris Prosaptia, In Z.Y Wu, P.H. Raven and D.Y. Hong, eds. Flora of China, Vol. 2-3 (Pteridophytes), Science Press (Beijing) \& Missouri Botanical Garden Press (St. Louis), 2013, pp. 846-848.

[9] C.L. Blume, Polypodium obliquatum, Enumeratio Plantarum Javae fasc., 2, J.W. Apud van Leeuwen, Lugduni Batavorum (Leiden), 1828, pp.128.

[10] http://rbg-web2.rbge.org.uk/thaiferns/factsheets/ index.php?q=Prosaptia_alata.xml

[11] http://bioportal.naturalis.nl/

[12] http://www.nhm.ac.uk/

[13] https://www.gbif.org/occurrence/1697870613

[14] C.H. Tian, C.H. Hsin, Y.L. Chien, L.C. Wen, M.H. Yao and H.C. Yi, New Additions to the Fern Flora of Taiwan (3), Taiwan J For Sci 30 (2) (2015) 135. https://doi.org/ 10.4103/UROS.UROS_142_18 